\title{
VIRGINIA WOOLF E A MULHER INGLESA DO INÍCIO DO SÉCULO XX: PHYLLIS E ROSAMOND À LUZ DA TEORIA SEMIOLINGUÍSTICA
}

Ednelza Magalhães Nunes Duarte da Silva Rita de Cássia Mendes Pereira

Resumo: O presente artigo se propõe a analisar, no conto "Phyllis e Rosamond", escrito por Virginia Woolf, em 1906, os possíveis interpretativos sobre a mulher de classe média inglesa do início do século XX. A autora tem um projeto de fala que, nesse texto, ela sustenta e organiza por meio do gênero narrativo. Para abordar a sua condição de sujeito da linguagem e suas conexões com os demais sujeitos compreendidos no ato comunicacional, a presente análise se apoia na Teoria Semiolinguística de Patrick Charaudeau e, particularmente, na noção de imaginários sociodiscursivos, compreendida como conceito chave para o desvendamento da realidade psicossociohistórica na qual estavam inseridas Virginia Woolf e sua obra. Complementarmente, o estudo toma como referência o quadro sobre os sujeitos da linguagem no modo de organização narrativo, de acordo com a proposição de Machado e Mendes. As autoras propõem diferenciar o sujeito social (Eu comunicante) do escritor, definido como sujeito narrativo. A noção de sujeito narrativo abarca, também, os múltiplos sujeitos da enunciação (narrador e personagens), com identidades discursivas distintas, mas que atuam de forma integrada aos propósitos do Eu comunicante e à concepção idealizada do Tu destinatário. Cada um desses sujeitos compreendidos pela noção de Eu enunciador consubstancia possíveis interpretativos sobre a mulher de classe média na Inglaterra do início do século XX. O jogo de contraditórios, articulado a partir do projeto de fala da escritora, visa, em última instância, desvelar e desconstruir os padrões de dominação próprios às sociedades patriarcais.

Palavras-chave: Teoria Semiolinguística. Imaginários Sociodiscursivos. Virginia Woolf. Possíveis Interpretativos.

Abstract: This paper aims to analyze the possible interpretations about the English middle-class woman of the early twentieth century represented in the short story "Phyllis and Rosamond", written by Virginia Woolf in 1906. In this text, the author has a speech project that 
is sustained and organized through the narrative genre. To deal with the author's condition as a subject of language and her connections with the other subjects involved in the communication act, this analysis is based on Patrick Charaudeau's Semiolinguistic Theory and, particularly, on the notion of socio-discursive imaginaries, taken as a key concept to throw light on the psychosocial history reality in which Virginia Woolf and her work were inserted in. In addition, the study takes as reference the language subjects framework adapted to narrative discourses, as proposed by Machado and Mendes. The authors' purpose is to differentiate the writer's social subject (I communicator), usually taken as a narrative subject. The notion of a narrative subject also integrates the multiple subjects of enunciation (narrator and characters), with distinct discursive identities, but acting in an integrated way to the purposes of the speaker (I communicator) and to the idealized conception of the listener (You addressee). Each of these subjects understood by the notion of I enunciator constitutes possible interpretative sums about the middle-class woman in England of the early twentieth century. The contradictory role articulated in the writer's speech project, at last, aims to reveal and deconstruct the domination pattern proper to patriarchal societies.

Keywords: Semiolinguistic Theory. Socio-discursive Imaginaries. Virginia Woolf. Possible Interpretations.

\section{INTRODUÇÃO}

A Análise do Discurso (AD) franco-brasileira considera que os sujeitos do discurso são psicosociohistóricos (MENDES, 2012). O ato de linguagem pressupõe procedimentos discursivos definidos em conformidade com o objetivo inicialmente delineado por aquele(s) que produz(em) e enuncia(m) o discurso mas, também, com as características e ações dos demais sujeitos da linguagem envolvidos no contrato de comunicação. Ao analista do 
discurso cabe, como procedimento fundamental, investigar quem são os sujeitos da linguagem, situá-los em contextos sócio-históricos, elucidar as finalidades discursivas que os mobilizam e os possíveis interpretativos implícitos do ato comunicacional. Nessa perspectiva, tomando como fonte o conto "Phyllis e Rosamond", escrito por Virginia Woolf, o presente artigo se propõe a evidenciar os possíveis interpretativos sobre a mulher inglesa do início do século $\mathrm{XX}$ e que, mediante estratégias próprias ao modo narrativo de organização do discurso, são postos em evidência no texto. Para essa abordagem é essencial, em primeiro lugar, afirmar a condição de sujeito social da autora, que, como Eu comunicante, dialoga com os imaginários sociodiscursivos que circulam na sociedade (CHARAUDEAU, 2017), mas, ao mesmo tempo, intenta um rompimento com convenções sociais vigentes.

A autora tem um projeto de fala, que ela organiza, nesse texto especificamente, por meio do gênero literário conto. No ato comunicacional, que envolve a produção e enunciação de discursos relativos à condição das mulheres, Woolf adota, como estratégias, a narrativa e o discurso direto livre. Essas formas permitem a projeção de vários sujeitos da linguagem, com peculiares identidades narrativas, 
apresentados com características psicosociohistóricas distintas. Por meio desses sujeitos se revelam os possíveis interpretativos em relação à condição das mulheres de classe média na Inglaterra no início do século XX.

Com base na Teoria Semiolinguística de Patrick Charaudeau (2014) e com apoio do quadro dos sujeitos da linguagem próprios ao discurso literário narrativo, de acordo com a proposição de Machado e Mendes (2014), o presente trabalho busca evidenciar como, nas circunstâncias de produção e enunciação do discurso, os possíveis interpretativos são construídos em estreita relação com o imaginário sociodiscursivo e com o efeito de sentido visado pela escritora.

\section{VIRGINIA WOOLF E O CONTO PHYLLIS E ROSAMOND NA INGLATERRA DO INÍCIO DO SÉCULO XX}

Virginia Woolf (1882-1941), nascida Adeline Virginia Stephen, em 25 de janeiro de 1882, era filha de Júlia e Leslie Stephen. Julia Prinsep Duckworth, viúva de Herbert Duckworth, casou-se com Leslie Stephen em 1878, trazendo consigo três filhos do casamento anterior - George, nascido em 1868; Stella, em 1869; e Gerald, em 1870. Leslie, por sua vez, trazia Laura, filha de seu primeiro casamento. Da união de Julia e Leslie Stephen nasceram Vanessa, em 1879; Thoby, 
em 1880; Adeline Virginia, em 1882; e Adrian, em 1883. A relação de Virginia com a família reflete a diversidade de afetos e experiências com os pais, com o grupo dos meioirmãos Duckworth e com os irmãos Stephen. Laura, por ser uma criança doentia, mantinha-se isolada dos demais (BELL, 1988).

É nessa estrutura familiar que Virginia, nos primeiros anos do século $X X$, inicia suas reflexões a respeito dos padrões de comportamento que limitavam as ações das mulheres. As convenções e a rigidez moral exaltadas no período que ficou conhecido como Era Vitoriana (18371901) ainda se faziam presentes durante a juventude de Virgínia, a reforçar valores e práticas patriarcais, e impactavam fortemente na definição dos papéis sociais atribuídos a homens e mulheres. Anthony Burgess descreve a Era Vitoriana da seguinte maneira:

Foi uma época de moralidade convencional, de grandes famílias em que o pai era uma espécie de chefe divino, e a mãe, uma criatura submissa como a Eva de Milton. A moralidade rígida, o caráter sagrado da vida em família eram devidos em grande parte ao exemplo da própria rainha Vitória, e sua influência indireta sobre a literatura, assim como sobre a vida social, foi considerável. (BURGESS, 2003, p. 215) 
Inserida no núcleo dos irmãos mais jovens, Virgínia tinha, no pai e nos meio-irmãos, exemplos de conformação ao modelo vitoriano de família. Destaca Alexandra Lemasson em sua biografia sobre Virginia Woolf: "Para Virginia, existe um fosso entre os filhos Stephen, de um lado, e Leslie, George e Gerald de outro. Enquanto os primeiros Ihe parecem representativos desse início de século XX, os demais encarnam a seus olhos o que a era vitoriana simboliza de mais retrógrado" (LEMASSON, 2011, p. 73).

A família Stephen poderia ser identificada com a ideia de classe média, que compreendia um amplo espectro de condições socioeconômicas. Destituídas de títulos nobiliárquicos e de capital, essas famílias empreendiam esforços de ascensão social por meio dos estudos e de vinculação à estrutura estatal, no caso dos homens, ou de casamentos proveitosos, principalmente no caso das mulheres. Desse modo, assim como sua mãe e irmãs, a jovem Virgínia tinha, como a maioria das mulheres do grupo social ao qual pertencia, seus lugares e papéis fixados no ambiente doméstico e seu processo formativo inicial estava voltado para a conquista do casamento. O seu pai era reconhecido como intelectual e os irmãos já se engajavam nos papéis de colegiais, estudantes universitários, funcionários 
públicos, em busca de independência financeira e boa reputação. Às mulheres da família, como aponta Quentin Bell, sobrinho e biógrafo de Virginia Woolf, não foi dada a opção de frequentar escolas. Elas eram instruídas em casa pelos pais e por professores especializados em habilidades específicas, como "desenho, dança, música e conduta graciosa", requisitos para "a aquisição de qualidades femininas" (BELL, 1988, p. 55).

As boas maneiras, distintas para homens e mulheres, eram requisitos para a manutenção do status advindo do nascimento e, principalmente, para o projeto de ascensão social que acabaria por favorecer todo o núcleo familiar. É esse o projeto que mobiliza, por exemplo, George Duckworth, meio-irmão de Virgínia, depois da morte da mãe, a iniciar as jovens irmãs na vida da "Sociedade". As suas incisivas tentativas de inserção de Vanessa e Virginia nos meios nobiliárquicos são abordadas no ensaio "22, Hyde Park Gate"1, escrito em 1920, que acabou integrado ao livro de escritos autobiográficos de Virginia Woolf intitulado Moments of being (1976), organizado por Quentin Bell e Angélica Garnett e publicado no Brasil sob o título Momentos de vida (WOOLF, 1986, p. 187-204).

1 22, Hyde Park Gate foi o endereço de Virginia Woolf no bairro de Kensington, Londres, desde 1882, ano de seu nascimento, até 1904, quando mudou-se para o 46, Gordon Square, Bloomsbury, após a morte de seu pai. 
De acordo com Woolf, George já usufruía de uma posição social vantajosa:

Ele era um solteirão de boa aparência, de cerca de trinta anos de idade, com uma renda de mais de mil libras por ano. Como secretário particular de Austen Chamberlain, ele era, naturalmente, convidado para todas as grandes festas de todos os grandes nobres. (WOOLF, 1986, p. 195)

Entretanto, ele nutria reverência pela nobreza britânica e havia decidido subir na escala social, com o auxílio de suas "mais pobres" e órfãs, porém "belas", irmãs. A mais velha, Vanessa, foi a primeira a ser iniciada, e, depois dela, Virginia. Woolf relata as suas experiências nos eventos sociais da alta sociedade londrina e as orientações recebidas do irmão:

Eu já estivera na Semana de Maio em Cambridge, e minhas lembranças eram tão boas que faziam com que eu me perguntasse por que Vanessa achava os bailes de Londres tão detestáveis. Algumas noites mais tarde, descobri por mim mesma. Depois de duas horas de pé no salão de baile de Lady Sligo, depois de esperar ser apresentada a rapazes estranhos, de dançar uma dança de roda com Conrad Russell ou com Esmé Howard, de dançar muito mal, de ficar sem par, de ouvir George me dizer que eu estava bonita, mas que devia manter as costas retas, retirei-me para uma ante-sala e coloqueime atrás de uma cortina, esperando que ela me ocultasse. Por algum tempo consegui 
esconder-me. No caminho de casa ele me elogiou afetuosamente, garantindo que eu precisava apenas de prática para ser um sucesso social. (WOOLF, 1986, p. 199)

As ações propostas pelo meio-irmão, baseadas em convenções e procedimentos próprios aos jogos de conquista, não foram bem-sucedidas. O objetivo era manter as moças em contato com os meios nobiliárquicos para que, ali, encontrassem oportunidades de ascensão por meio do casamento. Entretanto, já nesta época, Virginia e Vanessa, cultivavam interesses em atividades artísticas e intelectuais que acabariam por definir o futuro de ambas: uma seria escritora e a outra, pintora. Isso as afastava dos projetos de George. Especialmente Virgínia, cuja escrita literária haveria de se tornar um foco permanente de tensões e questionamentos sobre o papel e a condição das mulheres (LEMASSON, 2011).

Embora tivesse origem em um círculo social conservador, marcado pela dominação patriarcal, que, comumente, excluía as mulheres do acesso à educação formal, há um aspecto que deve ser considerado no processo de formação intelectual de Virgínia e na sua atuação como escritora. Filha de um escritor influente e respeitado, ela viveu a infância inserida em uma rede de relações sociais onde circulavam, 
presencialmente ou por meio de cartas, intelectuais como George Meredith (1828-1909), John Morley (1838-1923), Thomas Hardy (1840-1928), Henry James (1843-1916), entre outros. A atmosfera literária do seu espaço doméstico e o livre acesso à biblioteca do pai certamente serviram de estímulo para que Adeline Virginia Stephen começasse a escrever desde cedo.

Depois da morte de Leslie Stephen, em 1904, os quatro filhos Stephen mudaram-se para 46, Gordon Square, em Bloomsbury. Ali, os irmãos de Virgínia passaram a receber, nas noites de quinta-feira, os colegas de Cambridge. Nessas reuniões formou-se o embrião do que mais tarde se tornaria o famoso Grupo de Bloomsbury, composto por artistas e intelectuais livre-pensadores como Clive Bell, Lytton Strachey, Leonard Woolf, Maynard Keynes, Roger Fry, entre outros (WOOLF, 1986). Virgínia casou-se, em 1912, com Leonard Woolf, e o casal Woolf fundou, em 1917, a editora Hogarth Press, que passou a publicar não só os próprios livros, como, também, trabalhos de outros escritores importantes à época, a exemplo de Katherine Mansfield, T. S. Eliot, E. M. Forster. Coube à Hogarth, também, a publicação da primeira tradução britânica da obra de Freud. 
Estudiosos da obra de Virginia Woolf consideram que a sua escrita foi inovadora, notadamente por dois aspectos. O primeiro diz respeito à técnica e ao estilo de narrativa que, ao incorporar o discurso indireto livre, permite a apresentação do "fluxo de consciência" de suas personagens (HUMPHREY, 1976; LEITE, 1993). Sobretudo nas suas obras da maturidade, a autora explora as experiências subjetivas dos personagens, de modo a induzir o leitor a refletir sobre o que acontece na mente dos sujeitos que povoam os seus textos. "Phyllis e Rosamond", primeiro texto literário publicado por Virginia Woolf, tem como característica fundamental a presença de um(a) narrador(a) onisciente, que apresenta a história de modo a situar o leitor no contexto social e histórico e esmiuçar o perfil psicológico das personagens. As estratégias utilizadas pela escritora revelam-se especialmente proveitosas para a análise dos sujeitos do discurso e dos possíveis interpretativos que, por meio daqueles, se revelam no conto.

O segundo aspecto frequentemente destacado como inovador na escrita de Virginia Woolf diz respeito à forma singular como os seus textos se engajam no debate sobre questões relativas à condição da mulher, aos seus direitos e ao seu papel social na sociedade (LEMASSON, 2011; OLIVEIRA, 
2012; CAMARGO, 2001). Woolf aponta para as desigualdades entre homens e mulheres e examina, com especial interesse, temas como a exclusão da mulher do ambiente público e do mundo da escrita. Em A Brief History of English Literature, John Peck e Martin Coyle destacam: "Tanto seus romances quanto seus ensaios reivindicam serem reconhecidos como portadores de uma crítica feminista altamente significativa, de fato inovadora, à exclusão das mulheres da independência econômica e intelectual" (PECK; COYLE, 2013, p. 258, tradução nossa).

À margem o debate sobre a pertinência da filiação de Virgínia Woolf ao que viria a ser considerada a "crítica feminista", efetivamente, a abordagem sobre as diferenças entre homens e mulheres está presente em seus romances e contos, bem como em seus ensaios críticos e literários. Um desses textos se configurou como uma contribuição duradoura para o debate sobre as relações de gênero e impactou, de forma decisiva, as várias correntes do feminismo no Ocidente, na contemporaneidade. Trata-se do ensaio crítico denominado A Room of One's Own, de 1929, traduzido para a língua portuguesa como Um teto todo seu (WOOLF, 2014). Neste trabalho, Virginia Woolf confere ao poder patriarcal, e ao autoritarismo que lhe é 
inerente, a responsabilidade sobre a opressão vivenciada pelas mulheres e atenta para uma das facetas dessa opressão: a ausência de mulheres no meio intelectual.

As críticas à condição da mulher no sistema patriarcal estão presentes, também, em "Phyllis e Rosamond", texto tomado aqui como fonte de investigação. O conto é uma narrativa ficcional sobre duas das cinco filhas de Mr William e Lady Hibbert, postas em contraponto com Miss Sylvia Tristram, personagem de destacada formação intelectual e ciosa da sua emancipação em relação aos padrões dominantes de comportamento feminino. Por meio das irmãs Phyllis e Rosamond Hibbert, da narrativa de suas ações e da forma como elas se expressam, Virginia Woolf expõe informações sobre o cotidiano da maioria das mulheres da classe média inglesa do início do século XX. A apresentação do comportamento e dos discursos atribuídos às personagens é frequentemente acompanhada de juízos de valor sobre as mulheres, especialmente sobre as moças solteiras, criadas como escravas dos salões. É o que se depreende do discurso transcrito a seguir, que Woolf faz enunciar pela voz do(a) narrador(a):

Vê-las na sala cheia de mulheres e homens bem trajados é como ver um negociante na Bolsa, ou um advogado no fórum. Esta, proclamam cada gesto e palavra, é sua inata 
aparência; este é o seu local de trabalho, sua arena profissional. Claramente é aqui que elas praticam as artes nas quais foram desde a infância instruídas. Aqui talvez ganhem o seu pão e obtenham a sua vitória. (WOOLF, 2005, p. 15)

Encontram-se aí explicitados os limites impostos às mulheres da classe média na sociedade inglesa do início do século $X X$ e, de forma irônica, por meio da voz narrativa, a autora ironiza a ideia corrente de que a única vitória tangível para essas mulheres era a conquista do casamento, que lhes garantiria a sobrevivência, o ganha-pão.

Como ser de fala, Woolf persegue o objetivo de denunciar a contradição inerente a esse projeto de vida: as mulheres mobilizam um esforço monumental para estar exatamente no lugar que permite ao homem exercer poder sobre elas e reproduzir as opressões inerentes ao sistema patriarcal. Ou seja, as mulheres estão envolvidas em um jogo estrutural, do qual os homens, soberanos, sempre saem vencedores. Entretanto, entre as estratégias discursivas utilizadas pela autora para alcançar o efeito visado, está a concessão do poder de fala aos distintos sujeitos que se encontram e, eventualmente, se confrontam na narrativa. Ela joga com os possíveis interpretativos sobre a condição das mulheres. À luz da Teoria Semiolinguística, o presente artigo pretende 
elucidar e situar esses possíveis interpretativos, enunciados pelos múltiplos seres de fala contemplados no conto, em relação ao imaginário sociodiscursivo sobre a condição das mulheres na sociedade inglesa do início do século XX.

\section{PRINCÍPIOS GERAIS E CONCEITOS CENTRAIS DA TEORIA SEMIOLINGUÍSTICA}

A Teoria Semiolinguística é um arcabouço teóricometodológico que se situa no campo da Análise do Discurso franco-brasileira, desenvolvida pelo linguista francês Patrick Charaudeau e adaptada para os trópicos, em especial para o Brasil, como um trabalho conjunto de pesquisadores de três Laboratórios de Pesquisa em Análise do Discurso: o CIAD-Rio (Centro Interdisciplinar de Análise do Discurso) da Faculdade de Letras UFRJ, o NAD (Núcleo de Análise do Discurso) da Faculdade de Letras da UFMG e o CAD (Centre d'Analyse du Discours) de Paris XIII, na França.

Para a Teoria Semiolinguística, os discursos devem ser analisados levando em consideração os sujeitos que interagem no processo de comunicação. Além disso, a análise de discursos deve considerar a finalidade que orienta o projeto de fala, que suscita a adoção de estratégias e modos particulares de organização do discurso. Em condições psicossociais específicas, os sujeitos interagem de 
acordo com as suas posições no contrato de comunicação. O resultado do ato linguageiro expressa os condicionantes próprios aos espaços externo e interno nos quais circulam os discursos, como pode ser visualizado no esquema exposto na Figura 1:

Figura 1 - $\mathrm{O}$ ato de linguagem e seus sujeitos, segundo Patrick Charaudeau

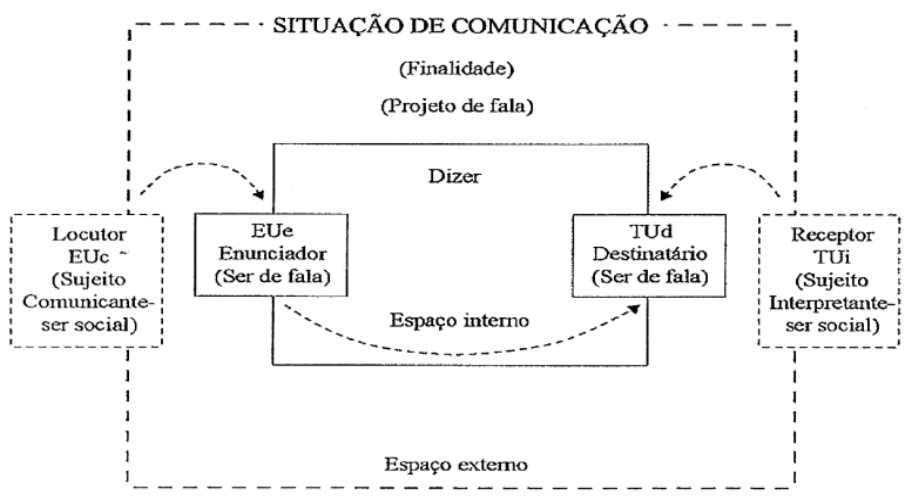

Fonte: Charaudeau, 2014.

A abordagem do ato de linguagem a partir da Teoria Semiolinguística busca, portanto, enfatizar, quem são os sujeitos da linguagem e quais os seus papéis no processo de comunicação. O resultado do processo de comunicação compreende tanto as intencionalidades declaradas do emissor quanto os sentidos construídos na relação que une o emissor ao receptor. Os sentidos possíveis respaldam características psicológicas e sociais dos sujeitos. Entretanto, produzido em um dado contexto psicossociohistórico por um emissor, do qual é possível 
se adivinhar uma intencionalidade, $\mathrm{o}$ ato de linguagem configura-se, como algo não-transparente:

$\mathrm{O}$ ato de linguagem não esgota sua significação em sua forma explícita. Este explícito significa outra coisa além de seu significado, algo que é relativo ao contexto sócio-histórico. Um dado ato de linguagem pressupõe que nos interroguemos a seu respeito sobre as diferentes leituras que ele é suscetível de sugerir. O que nos leva a considerá-lo como um objeto duplo, constituído de um Explícito (o que é manifestado) e de um Implícito (lugar de sentidos múltiplos que dependem das circunstâncias de comunicação). (CHARAUDEAU, 2014, p. 17)

Charaudeau atenta para a dupla dimensão do fenômeno linguageiro, que envolve duas atividades: a simbolização referencial e a significação. A primeira está relacionada com a atividade estrutural e se dá no jogo de reconhecimento morfossemântico construtor de sentido, que remete à realidade que rodeia os sujeitos, conceituando-a. A significação, por sua vez, diz respeito à linguagem como condição de realização dos signos, de modo que "estes não signifiquem mais por si mesmos, mas por uma totalidade discursiva que os ultrapassa" (CHARAUDEAU, 2014, p. 25).

Nessa perspectiva, a simbolização referencial está em correlação com o Explícito da linguagem, que apresenta 
uma configuração semiológica incompleta e que mantém uma relação de interdependência com a significação e, por conseguinte, com a dimensão Implícita, que provém das circunstâncias de produção e interpretação do ato de linguagem, isto é, das circunstâncias do discurso.

As circunstâncias do discurso remetem aos saberes que os participantes do ato de linguagem partilham. A forma de compartilhamento dos saberes envolve dois aspectos das condições de produção e de interpretação do ato da linguagem: a) a relação dos sujeitos com o propósito linguageiro; b) a relação que os sujeitos mantêm entre si. As circunstâncias do discurso são o palco de um jogo que envolve, de um lado, os sujeitos da produção e enunciação discursiva e, do outro lado, os receptores da mensagem. No processo de interação esses sujeitos formulam hipóteses um sobre o outro e ambos sobre o sentido do ato de linguagem. Para sintetizar essa situação, podemos dizer que "o sujeito interpretante está sempre criando hipóteses sobre o saber do enunciador [...]. De forma análoga, [...] para o sujeito enunciador, falar ou escrever é uma atividade que envolve criação de hipóteses sobre o saber do sujeito interpretante" (CHARAUDEAU, 2014, p. 31). Complementa Charaudeau:

Quando definimos as circunstâncias do discurso, vimos que $o$ ato de linguagem, como 
evento de produção ou de interpretação, depende 'dos saberes supostos que circulam entre os protagonistas da linguagem'. Esses saberes são correlativos à dupla dimensão Explícito/Implícito do fenômeno linguageiro. Tal fato confirma a assimetria observada [...] entre o processo de produção e o processo de interpretação do ato de linguagem. (CHARAUDEAU, 2014, p. 44)

A relação dialética entre o processo de produção e o processo de interpretação é essencial à compreensão do Ato de Linguagem. Charaudeau refere-se a esse ato como uma encenação (mise em cène), que se desenvolve em um circuito interno e um circuito externo de comunicação. No circuito externo se encontram o EU comunicante (EUc) e o TU interpretante (TUi). O EUc é o responsável pela concepção e pela produção do discurso. Ele se institui como articulador da palavra e almeja o domínio sobre o TUi.

No circuito interno se encontram o Eu enunciador (EUe) e o TU destinatário (TUd). O EUe põe em cena as intenções do EUc e mantém relação direta com o TUd, que é uma representação idealizada do TUi. O EUe e o TUd são sujeitos que existem no e pelo discurso e concedem materialidade ao projeto de fala do Eu comunicante no ato de linguagem. Mas o sujeito interpretante (TUi), independente das intencionalidades que orientam os processos de produção 
e enunciação discursiva, se apropria da mensagem do EUe, originalmente construída pelo EUc, e, no processo de interpretação, tendo como referência os seus próprios saberes, cria hipóteses não necessariamente afinadas com as pretensões do EUc. As possibilidades interpretativas podem coincidir ou não com as intenções projetadas, o que remete à assimetria do ato linguageiro.

Para que haja sucesso no projeto de comunicação, produtores e enunciadores organizam e comunicam o discurso por meios que tornem viável o contrato de comunicação e definem estratégias discursivas adequadas à consecução do efeito visado. O contrato de comunicação é socioconstitucional e pressupõe saberes partilhados entre os participantes da troca linguageira. Esses saberes são da ordem das convenções, das regras, das práticas sociais, dos acordos entre os sujeitos da comunicação. 0 reconhecimento do contrato pelos indivíduos envolvidos no ato de linguagem é o que permite que eles se intercompreendam e compreendam a finalidade de tal ato.

A noção de contrato pressupõe que os indivíduos pertencentes a um mesmo corpo de práticas sociais estejam suscetíveis de chegar a um acordo sobre as representações linguageiras dessas práticas sociais. Em decorrência disso, o sujeito comunicante sempre pode supor que o outro possui uma 
competência linguageira de reconhecimento análoga à sua. Nessa perspectiva, o ato de linguagem torna-se uma proposição que o EU faz ao TU e da qual ele espera uma contrapartida de conivência. (CHARAUDEAU, 2014, p. 56)

Mediante estratégias discursivas particulares, o sujeito comunicante "concebe, organiza e encena suas intenções" com a finalidade de "produzir determinados efeitos de persuasão ou de sedução" no sujeito interpretante (TUi). Essa atitude do EUc visa fazer com que o TUi se identifique com o sujeito destinatário idealizado (TUd). Por outro lado, o sujeito da enunciação (EUe), que nem sempre coincide com o sujeito comunicante, pode lançar mão de outras estratégias, visando promover efeitos de identificação, de patemização ou racionalização no receptor da mensagem. De acordo com Charaudeau (2014), os efeitos de identificação decorrem da atuação do Eu comunicante, no sentido de criar para si uma imagem determinada e apostar na identificação do receptor com essa imagem. O efeito de patemização decorre da criação, pelo EUc, de situações discursivas capazes de provocar emoções no interlocutor. Os efeitos de racionalização pressupõem o uso de estratégias de argumentação capazes de convencer o Tu interpretante. O sucesso dessas estratégias pressupõe, entretanto, a 
existência de imaginários sociodiscursivos compartilhados entre os vários sujeitos da comunicação.

A ideia de imaginários sociodiscursivos é essencial ao desvendamento dos mecanismos pelos quais determinados significados, reproduzidos e compartilhados pelos indivíduos, circulam socialmente e se concretizam na realidade objetiva. $A$ noção, cara ao campo da análise do discurso, resulta da tentativa de compreender como e em quais situações determinadas ideias e comportamentos se sedimentam e são incorporados à prática coletiva. Para a sua formulação, Charaudeau (2017) valeu-se do conceito de representações sociais, da maneira como ele está configurado no campo da Psicologia Social.

Os sujeitos sociais avaliam um determinado objeto e constroem para ele um significado, que passa a ser reproduzido e compartilhado pelo grupo, incorporado ao senso comum e transformado em regra de comunicação. Essa flutuação e fluidez na construção das representações sociais é o que mais interessa a Charaudeau. O teórico acredita que as interações sociais e os usos que os sujeitos fazem das representações funcionam como mecanismos para a construção da noção de imaginários:

De minha parte, retomarei, então, essa noção em sua definição, não como um conceito, mas como um mecanismo de construção 
do sentido que modela, formata a realidade em real significante, engendrando formas de conhecimento da "realidade social". Nessa perspectiva, as representações sociais não são um subconjunto dos imaginários ou das ideologias como outros propõem [...], mas uma mecânica de engendramento dos saberes e dos imaginários. (CHARAUDEAU, 2017, p. 576)

À expressão imaginários, apropriada da Psicologia Social, Charaudeau adenda a contribuição específica da semiolinguística, mediante a incorporação da expressão "sociodiscursivos". Para construir um percurso lógico do conceito de imaginários sociodiscursivos, Charaudeau propõe distinguir os conceitos de imaginário, de imaginário social e de imaginário sociodiscursivo. Sobre a noção de imaginário, afirma:

É uma forma de apreensão do mundo que nasce na mecânica das representações sociais, a qual, [...] constrói a significação sobre os objetos no mundo, os fenômenos que se produzem, os seres humanos e seus comportamentos, transformando a realidade em real significante. Ele resulta de um processo de simbolização de ordem afetivoracional através da intersubjetividade das relações humanas, e se deposita na memória coletiva. (CHARAUDEAU, 2017, p. 578)

sentido social do imaginário ocorre "à medida que esta atividade de simbolização representacional do mundo se faz 
dentro de um domínio de prática social (artística, política, jurídica, religiosa, educativa, etc.)" (CHARAUDEAU, 2017, p. 578). Os imaginários nascem no campo social e ganham expressão e coerência com a ordem social com a ajuda dos aparelhos de regulação, que são as instituições.

Por fim, os imaginários podem ser caracterizados como discursivos quando se manifestam por meio da fala. Pois é por meio da fala que os saberes gerados pela mecânica das representações sociais se estruturam e sedimentam discursos narrativos e argumentativos, tornando possível uma descrição das coisas e dos comportamentos no mundo. Os imaginários são, portanto, sociais e discursivos.

\section{IMAGINÁRIOS SOCIODISCURSIVOS E POSSÍVEIS INTERPRETATIVOS SOBRE A CONDIÇÃO DAS MULHERES NA NARRATIVA FICCIONAL PHYLLIS E ROSAMOND}

A questão essencial que orientou a investigação sobre o conto "Phyllis e Rosamond", de Virgínia Woolf, foi: quais os possíveis interpretativos sobre a condição da mulher inglesa do início do século XX que a autora mobilizou, no processo de produção e enunciação do texto, com o intuito de efetivação de sua finalidade? Tal questão encontra-se em consonância com a pergunta chave proposta por Charaudeau em suas reflexões sobre linguagem e discurso: "quais sujeitos o texto faz falar?" (CHARAUDEAU, 2014, p. 63). 
No caso específico do texto aqui tomado como objeto de análise, o discurso é enunciado por meio do gênero literário conto. Por esta razão o quadro dos sujeitos da linguagem em gêneros subordinados aos modos de organização narrativo, proposição de Machado e Mendes (2012) disposto na Figura 2, será tomado como referência para tratar do ato de comunicação:

Figura 2-Quadro dos sujeitos da linguagem para gêneros literários com modos de organização narrativo

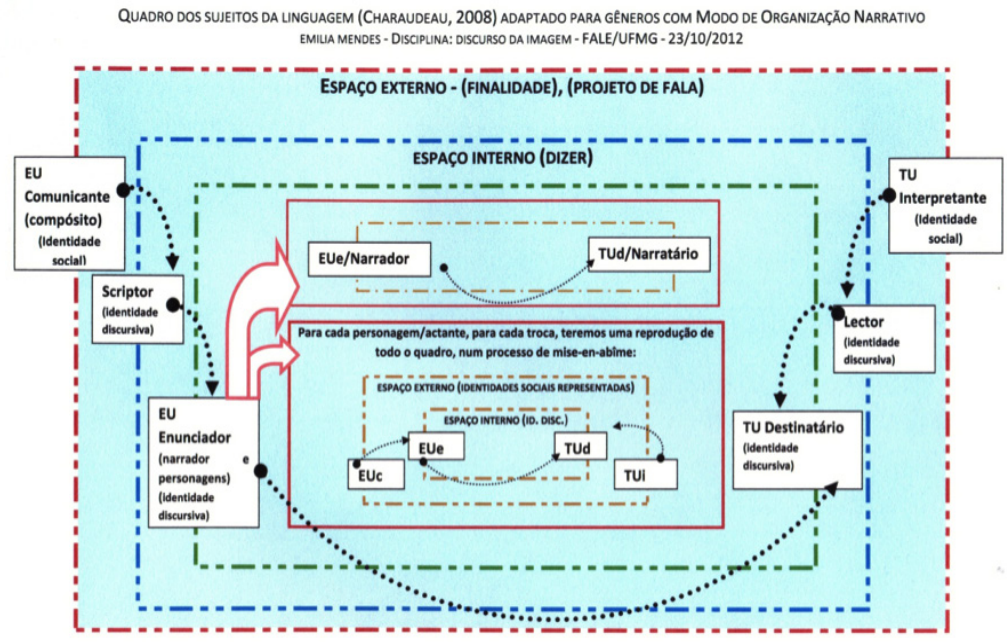

Fonte: Machado e Mendes (2012)

De acordo com a proposição de Machado e Mendes (2012), no espaço externo da situação de comunicação estão situados, de um lado, o EU comunicante, sujeito com corpo físico e identidade social, que elabora o discurso de acordo com o seu projeto de fala; e, do outro lado, um TU 
interpretante, que também tem corpo físico e identidade social. $\mathrm{O}$ ato de comunicação entre esses sujeitos realizase, a princípio, de acordo com a finalidade do primeiro, mas o Tu interpretante, com os seus próprios saberes, tem autonomia para a formulação de hipóteses relativas às proposições daquele.

Para empreender o seu discurso e fazê-lo chegar ao público (TU interpretante), o EU comunicante, aqui identificado como Virginia Woolf, lança mão de um sujeito discursivo militante, o scriptor, definido como um ser de papel que tem a função de estruturação discursiva do conto de acordo com o seu projeto de fala. O scriptor se comunica com o lector, que, assim como o scriptor, tem também tem uma identidade discursiva. Ao leitor, cabe reconhecer as pistas linguísticas do scriptor e, a partir delas, posicionar-se em relação ao seu projeto.

O projeto de fala de Virgínia Woolf, identificado aqui como scriptor, orienta-se pelo propósito de "tirar da sombra" as mulheres da classe média, seus modos de vida e sentimentos e incitar a formação de juízo de valor sobre as opressões às quais elas estavam subordinadas. Mas, como ressalta Charaudeau, "a finalidade do ato de linguagem (tanto para o sujeito enunciador quanto para o 
sujeito interpretante) não deve ser buscada apenas na sua configuração verbal, mas, no jogo que um dado sujeito vai estabelecer entre esta e seu sentido implícito" (2014, p. 24). Assim, no ato de linguagem, que se consolida na relação dialética entre o processo de produção e o processo de interpretação, o explícito se manifesta como configuração verbal, mas, para o desvendamento do implícito, devem ser consideradas as condições psicosociohistóricas nas quais a escritora viveu e, ainda, os seus outros escritos sobre as condições da mulher na sociedade.

O texto escrito circula no espaço interno do discurso, onde se inscrevem o EU enunciador, representado pelos narradores e pelos personagens, com suas demandas, aflições, desagrados, denúncias ou conformações. Os sujeitos identificados como EU enunciador se dirigem ao TU destinatário, sujeito idealizado, ao qual se atribui uma identidade discursiva e a capacidade de reconhecer e se identificar com a mensagem. No espaço interno do discurso se definem os termos de materialidade linguística que permite que o enunciador seja ouvido, lido, confirmado, refutado ou questionado. É neste espaço que se estrutura a narrativa e que emergem os possíveis interpretativos sobre a mulher inglesa do início do século XX. 
A existência de imaginários sociodiscursivos compartilhados não apaga a possibilidade de enunciação de discursos divergentes, que ganham materialidade linguística na voz narrativa e por intermédio das personagens. As múltiplas interpretações sobre a condição das mulheres e as práticas conflitantes que emanam desses discursos põem em relevo uma realidade - estando inclusas nesta ideia de realidade as representações do real - que, por vezes, se pretende apresentar como uniforme.

Logo no primeiro parágrafo, o(a) narrador(a) se propõe a fazer um esboço, um contorno fiel e honesto, das mulheres, das suas indumentárias como do que se passava em suas mentes. Tirar as mulheres da sombra é o objetivo explícito de Woolf, enunciado na primeira pessoa do plural. Entretanto, toda a parte inicial do conto dedica-se a olhar para um pequeno grupo, que a autora afirma ser a síntese de muitos. Sua atenção está voltada, inicialmente, a perscrutar os atributos e o que ela define como "problemas" inerentes a esse grupo, representado pelas senhoritas Phyllis Rosamond, duas moças de 24 e 28 anos, as duas filhas "caseiras" do casal Hilbert, que parecem absolutamente conformadas em relação ao padrão esperado das mulheres solteiras de sua classe. As idades são enfatizadas com o intuito de frisar o 
quanto elas se encontravam pressionadas a encontrar, com urgência, maridos que pudessem lhes garantir a sobrevivência no futuro. As expectativas e o modo de vida das duas personagens são confrontados, logo no início, pelo destino de duas outras irmãs, que seguem caminhos diversos, e, nas páginas finais, pela experiência por elas vivenciada na casa de Sylvia Tristram, moça de formação intelectual apurada e ciosa de sua própria independência, embora oriunda do mesmo círculo social das primeiras.

Em uma época em que vigorava, ainda, a restrição de acesso à educação formal pela maioria das mulheres, a senhorita Tristram insere-se no conto como um espelho invertido das Hilbert. Ela põe a nu a condição de subalternidade na qual se encontrava a maioria das mulheres e, mais do que isso, em perfeita consonância com a intencionalidade do Eu comunicante, confronta o conformismo das Hilbert com discursos e práticas, com questionamentos e ironias, e aponta para a possibilidade de superação da situação de opressão na qual aquelas se encontram.

No papel de escritora, sujeito discursivo militante, Woolf joga com as experiências contraditórias das personagens de modo a tornar visíveis as limitações impostas às mulheres naquela sociedade, ou pelo menos no ciclo social ao qual 
ela se encontrava vinculada, em que ainda imperavam as convenções e a rigidez moral da era vitoriana. O imaginário sociodiscursivo dessa sociedade reverbera a assertiva de que nascer mulher era uma desgraça que se abatia sobre toda a família, como pode ser lido na passagem inicial do conto, quando a voz narrativa faz a apresentação das duas protagonistas e de suas irmãs: "São cinco filhas, todas mulheres, como lhe explicarão com pesar: lamentando esse erro inicial, ao que parece pela vida afora, que seus pais cometeram" (WOOLF, 2005, p. 14, grifo nosso).

Para superar esse "erro lamentável" que era a geração de filhas, a família tradicional deveria se voltar para a conquista de um casamento promissor para cada uma delas. Prover os meios pelos quais elas pudessem cultivar a independência econômica e intelectual estava totalmente fora de propósito. Subordinadas aos "costumes" que regiam as relações entre homens e mulheres, as moças levavam, de acordo com a narrativa de Woolf, uma vida de escravidão. O cultivo à beleza física e a frequência a compromissos sociais eram os únicos caminhos que poderiam resultar em uma proposta de casamento, como se apreende da voz narrativa, em sua descrição das personagens-título:

Um olhar minucioso não encontrará em seus traços uma beleza perfeita; mas seus trajes e 
maneiras darão-Ihes o efeito de beleza sem Ihes dar a substância. Parecem nativas das salas de visita, como se, nascidas em vestidos de seda para a noite, jamais tivessem posto o pé num solo mais irregular do que o tapete turco, ou reclinado em uma superfície mais áspera do que a poltrona ou o sofá. (WOOLF, 2005, p. 14-15)

Para as mulheres que se mobilizavam em busca de um bom casamento, o amor era um elemento secundário, subordinado à perspectiva econômica. Mas o sucesso na empreitada demandava práticas de conquista, aprendidas e amadurecidas na vivência cotidiana: “O amor para elas era algo induzido por determinadas ações bem calculadas; e que se acalentava nos salões de baile, ou dentro de odorosas estufas, por relances de olhos, por manobras do leque ou por um jeito de falar sugestivo e trêmulo" (WOOLF, 2005, p. 24).

Sobre o casamento, Rosamond resume: "Eu até acho o casamento a melhor coisa que existe - se nos permitissem casar com o homem que a gente quer" (WOOLF, 2005, p. 14). O jogo da conquista pode até ser tomado como uma oportunidade de diversão, como salienta Phyllis. Entretanto, às duas irmãs, conformadas com a ausência da liberdade, não é concedido o direito de viver um amor sincero, posto desnudo e sólido à luz do dia, como observa a voz narrativa: 
Phyllis e Rosamond, ainda que fossem livres para amar como escolhessem, sentiam-se em grande dúvida de que pudessem amar de tal maneira. Com o rápido impulso da juventude, elas se reprovaram terminantemente, concluindo que eram vãos todos os seus esforços de liberdade: quer por fora, quer por dentro, o longo cativeiro as corrompera. (WOOLF, 2005, p. 24)

O avançar da idade é para elas motivo de grande preocupação, como para a grande maioria das moças solteiras que, sob pressão dos pais, e principalmente da mãe, começam a cogitar um casamento sem muitas exigências. Sobre as irmãs Hibbert, a voz narrativa expõe:

Elas eram rigorosamente honestas em todas as transações que efetuavam juntas; e há até mesmo algo de cavalheiresco na atitude da irmã mais nova para com a mais velha. Sendo essa a mais fraca, por ser a que já tem mais idade, deve sempre ficar com a melhor parte. Há algo de tocante também na gratidão com que Phyllis aceita tal vantagem. (WOOLF, 2005, p. 16)

Entre as duas irmãs vigorava um sentido de cumplicidade que, entretanto, não resultava na fusão de forças para o rompimento com os costumes vigentes, mas na definição de estratégias de conformação ao modelo e de proteção mútua.

Por meio de Phyllis e Rosamond, Woolf expõe os costumes das famílias da classe média, que criavam as 
filhas para que se tornassem sedutoras e "anjos do lar". Essa última expressão viria a se consolidar em um ensaio de Virginia Woolf apresentado, anos mais tarde, em reunião da Sociedade Nacional de Auxílio às Mulheres, mas, já nesse conto da juventude, a autora antecipa a imagem, em clara referência ao padrão de comportamento feminino desejado pela sociedade patriarcal.

As moças eram educadas para, em dedicação devota, cuidar dos seus lares, tornando-os um ambiente belo e acolhedor para os maridos. Elas próprias deveriam se fazer belas para recebê-los. O bom desempenho na organização e no adorno das casas se complementava, mais tarde, com a chegada dos filhos, aos quais elas deveriam estender os cuidados dedicados aos maridos e a si próprias.

Em seu esforço por resgatá-las das sombras, Woolf acentua, nas imagens e discursos sobre as protagonistas (e sobre o grupo que elas representam), a ausência de liberdade, a submissão às vontades dos pais, a adequação às convenções sociais. Mas não as apresenta destituídas da consciência e da capacidade de reflexão sobre os limites, como expressam em conversas privadas.

A presença das irmãs na casa dos Tristram insere, na narrativa, um ponto de conflito, de confronto entre 
possibilidades que poderia resultar em uma ruptura. A primeira imagem vista por Phyllis diante da casa, na qual já se encontrava Rosamond, foi a de janelas com luz, "que deixavam derramar-se na rua um pouco da conversa e da vida que ocorriam lá dentro" (WOOLF, 2005, p. 22). O jogo de claro e escuro, com o qual a autora brinca desde o início da narrativa chega aqui ao seu ápice. No interior da casa, dos debates mais intensos aos comentários mais triviais, tudo concorria para tirar as mulheres da sombra e tornar explícitos os temas e comportamentos que as distinguiam naquele ambiente iluminado. Especialmente o casamento, para o espanto das protagonistas, é abordado na casa "sob uma luz nova e suficientemente alarmante" (WOOLF, 2005, p. 24).

Em diálogo com a jovem anfitriã, a bela e promissora artista Sylvia Tristram, Phyllis demonstra que não é impossível às mulheres desvendar o sistema de opressão ao qual estão submetidas, mas infere que dele não é possível escapar. 0 seu discurso, enunciado com "expressão sombria e sôfrega" corrobora a ideia de que a servidão e a liberdade são condições ontológicas ou frutos da providência. Em resposta à provocação da senhorita Tristram não se esquiva de afirmar a condição de subalternidade que define as suas ocupações, 
em contraposição à realidade vivenciada por outras moças, às quais havia sido concedido o privilégio de ser livre:

"O que você faz?", perguntou bruscamente, a fim de ir direto ao assunto.

"Que faço eu?", ecoou Phyllis. "Oh, mando servir o jantar e arrumo as flores!"

"Mas qual é sua ocupação?", prosseguiu Sylvia, que estava decidida a não se deixar levar por fraseados.

"Esta é minha ocupação; e eu gostaria que não fosse! Não se esqueça, Miss Tristram, de que a maioria das moças de família são escravas; e não convém que você me insulte por ter the acontecido ser livre". (WOOLF, 2005, p. 25-26)

A rápida passagem de Phyllis e Rosamond pelo ambiente de liberdade vigente na casa dos Tristram serve ao propósito de Woolf, de desvelar as múltiplas possibilidades de atuação social das mulheres. No retrato de Phyllis e Rosamond, endereçado a um destinatário idealizado, a escritora descortina uma realidade social que, na sua opinião, é perversa para a maior parte das mulheres de classe média na sociedade inglesa do início do século XX. O retrato é construído por meio de múltiplas vozes que se somam na condição de enunciadoras do discurso.

A legitimidade e autoridade de Woolf enquanto sujeito do discurso advém do controle sobre saberes que à maioria das mulheres não é concedido partilhar. Como Eu comunicante, ela se dirige ao público - o Tu interpretante - com o intuito de 
promover a reflexão e a crítica sobre a condição das mulheres na sociedade patriarcal. Com esse objetivo, ela mobiliza disposições partilhadas no imaginário sociodiscursivo e joga com os possíveis interpretativos sobre a realidade. São postos em evidência, ao longo da narrativa, discursos e modelos contraditórios de comportamento e pensamento. Phyllis e Rosamond mostram-se cientes de seus próprios limites e acham-se conformadas à subalternização, mas as ideias e práticas de contestação estão ali presentes na voz narrativa, na personagem de Sylvia Tristram, e, mesmo, em arroubos de consciência que, vez por outra, as protagonistas deixam escapar.

A onipresença da voz narrativa, enunciada em primeira pessoa do plural, insere-se entre as estratégias discursivas utilizadas por Woolf para produzir, no público, efeitos de patemização em relação às mulheres retratadas. Ou seja, a narrativa ficcional deve servir para provocar emoções, sensibilizar leitores e leitoras e conduzi-los à adoção de práticas sociais divergentes em relação aos modelos consagrados de comportamento de homens e mulheres.

\section{CONSIDERAÇÕES FINAIS}

O conto "Phyllis e Rosamond" evidencia e mobiliza os imaginários sociodiscursivos sobre a mulher inglesa de classe 
média do início do século $\mathrm{XX}$, subalternizada pelo modelo de sociedade patriarcal e, em especial, ainda calcada sobre o modelo vitoriano de comportamento. No circuito interno da comunicação, compreendido como o espaço do dizer, a voz narrativa e as personagens mulheres encontram-se unificadas na consideração de que a maior parte das mulheres encontra-se, de algum modo, em situação de submissão a algum tipo de servidão. Mas a trama se caracteriza pelo caráter polifônico, próprio ao texto narrativo. Os sujeitos discursivos delineados pela escritora exibem discursos e ações diferenciados, embora todos esses discursos estejam, de algum modo, subordinados ao propósito, à intencionalidade, que orienta a atuação de Virgínia Woolf, em suas identidades social e narrativa. A autora de "Phyllis e Rosamond" mobiliza os imaginários sociodiscursivos sobre a mulher que circulavam na Inglaterra do início do século XX com o claro objetivo de suscitar a reestruturação desses imaginários em um contínuum social e, na prática, promover mudanças na condição das mulheres subalternizadas. Como aponta Mendes (2012, p. 18), "a sociedade influencia a ficção, e a ficção, por sua vez, também influencia a sociedade". Entretanto, os sujeitos psicossociolinguageiros que atuam no circuito externo da comunicação compreendem também o Tu interpretante, que, em uma relação dialética construída nos 
processos de produção e interpretação, podem protagonizar atitudes não necessariamente afinadas com o efeito visado pelos produtores e enunciadores.

No circuito interno da comunicação, a voz narrativa é o sujeito onisciente, que busca pormenorizar os dados sobre o contexto social, histórico e psicológico das personagens os múltiplos Eus narrativos que se encontram na trama. De acordo com Machado e Mendes, "cada testemunha que dá seu depoimento consiste em um EU que está numa relação de encaixe em relação à voz do narrador e assume a posição de personagem" (2012, p. 14).

A análise do conto "Phyllis e Rosamond", a partir das contribuições da Teoria Semiolinguística e do quadro dos sujeitos da linguagem adaptado ao discurso literário por Mendes \& Machado (2012), aponta que a estrutura narrativa possibilita expor, de acordo com o projeto de fala de Virgínia Woolf, os possíveis interpretativos sobre a mulher de classe média na Inglaterra do início do século XX. Esses possíveis interpretativos encontram-se consubstanciados nos enunciados discursivos atribuídos ao sujeito da narração e às personagens postas em cena pela autora em um jogo de contraditórios que visa, em última instância, confrontar o imaginário sociodiscursivo dominante e desconstruir, 
mediante o desvelamento, os padrões de dominação próprios às sociedades patriarcais.

\section{REFERÊNCIAS}

BELL, Quentin. Virginia Woolf: uma biografia. Tradução de Lya Luft. Rio de Janeiro: Editora Guanabara, 1988.

BURGESS, Anthony. A literatura Inglesa. São Paulo: Ática, 2003.

CAMARGO, Mônica Hermini de. Versões do Feminino: Virginia Woolf e a estética feminista. 2001. Dissertação (Mestrado em Letras) Universidade de São Paulo, São Paulo, 2001.

CHARAUDEAU, Patrick. Linguagem e discurso: modos de organização. São Paulo: Contexto, 2014.

CHARAUDEAU, Patrick. Os estereótipos, muito bem. Os imaginários, ainda melhor. Entrepalavras, Fortaleza, v. 7, p. 571-591, janeiro/junho de 2017. HUMPHREY, Robert. O fluxo da consciência: um estudo sobre James Joyce, Virginia Woolf, Dorothy Richardson, William Faulkner e outros. São Paulo: McGraw-Hill do Brasil, 1976.

LEITE, Ligia Chiappini Moraes. O foco narrativo. São Paulo: Ática, 1993. LEMASSON, Alexandra. Virginia Woolf. Porto Alegre: L\&PM Pocket, 2011. MACHADO, Ida Lúcia; MENDES, Emília. A análise Semiolinguística: seu percurso e sua efetiva tropicalização. Revista Latinoamericana de Estudios del Discurso, v. 13, p. 7-20, 2013.

MENDES, Emília. Algumas configurações dos imaginários e dos ethé de "ladrão" na cultura brasileira. EID\&A - Revista Eletrônica de Estudos Integrados em Discurso e Argumentação, v. 3, 2015. Disponível em: http://periodicos.uesc.br/index.php/eidea/article/view/414. Acesso em: 29 dez. 2019.

OLIVEIRA, Maria Aparecida de. Three Guineas e a crítica literária feminista: revisão e releitura. Estação Literária Londrina, v. 9, p. 204-219, junho de 2012. Disponível em: http://www.uel.br/pos/letras/EL/. Acesso em: 9 fev. 2021 
PECK, John; COYLE, Martin. A Brief History of English Literature. London: Palgrave Macmillan, 2013.

WOOLF, Virginia. Contos completos: Virginia Woolf. Tradução de Leonardo Fróes. Fixação de textos e notas de Susan Dick. São Paulo: Cosac Naify, 2005.

WOOLF, Virginia. Momentos de Vida: um mergulho no passado e na emoção. Joanne Schulkind (Org.).Tradução de Paula Maria Rosas. Rio de Janeiro: Nova Fronteira, 1986.

WOOLF, Virginia. Um teto todo seu. Tradução de Bia Nunes de Sousa e Glauco Mattoso. São Paulo: Tordesilhas, 2014.

\section{Rita de Cássia Mendes Pereira}

Doutora em História Social pela USP, com Pós-doutorado em História pela UFBA.

Docente do Programa de Pós-graduação em Letras: Cultura, Educação e Linguagens e do Mestrado Profissional em História da UESB.

E-mail: rita.pereira@uesb.edu.br

Lattes: $\underline{\text { https://lattes.cnpq.br/8786847939769955 }}$

ORCID iD http://orcid.org/0000-0003-1013-4267

\section{Ednelza Magalhães Nunes Duarte da Silva}

Mestranda do Programa de Pós-graduação em Letras: Cultura Educação e Linguagens da UESB.

Professora de Língua Inglesa da Secretaria Estadual de Educação - Ba.

E-mail: ednelzadi@gmail.com

Lattes: $\underline{\text { http://lattes.cnpq.br/9391587123206349 }}$

ORCID iD: https://orcid.org/0000-0002-9312-3266 